\title{
Metode Pendidikan Shalat pada Anak Usia 5-10 Tahun dalam Keluarga
}

\author{
Muhammad Sopiyana $^{1}$, Septian Arief Budiman ${ }^{2}$ \\ ${ }^{1}$ Universitas Pamulang, Indonesia \\ ${ }^{2}$ Universitas Pamulang, Indonesia \\ 1dosen01126@unpam.ac.id
}

\begin{abstract}
Abstrak:
Penerapan pendidikan di lingkungan keluarga sering menjadi kendala khusunya bagi orang tua tidak terkecuali bagi orang tua yang berprofesi sebagai guru, diperlukan metode khusus karena yang dihadapi adalah anak kandungnya sendiri, penelitian ini bertujuan untuk mendapatkan solusi dan metode pembelajaran yang tepat untuk pendidikan shalat di lingkungan keluarga guru, metode penelitian yang digunakan pada penelitian ini adalah kualitatif deskriptif dengan pengumpulan data melalui wawancara, hasil yang didapat dari penelitian ini ialah metode pembelajaran sholat pada anak guru dengan menggunakan pembiasaan dan penteladanan orang tua kepada anakny-anaknya.
\end{abstract}

Kata Kunci: Pendidikan Shalat, Pendidikan Keluarga, Anak-anak

\begin{abstract}
:
The application of education in the family environment is often an obstacle especially for parents, not least for parents who work as teachers, special methods are needed because what is faced is their own biological children, this study aims to obtain appropriate learning solutions and methods for prayer education in the family environment teacher, the research method used in this research is descriptive qualitative by collecting data through interviews, the results obtained from this study are prayer learning methods for teachers' children by using habituation and parental modeling to their children.
\end{abstract}

Keywords: Prayer Education, Family Education, Todler 


\section{Pendahuluan}

Keluarga adalah lembaga yang sangat penting dalam proses pengasuhan anak. Meskipun bukan satu-satunya faktor, keluarga merupakan unsur yang sangat menentukan dalam pembentukan kepribadian dan kemampuan anak. Secara teoritis dapat dipastikan bahwa dalam keluarga yang baik, anak memiliki dasar-dasar pertumbuhan dan perkembangan yang cukup kuat untuk menjadi manusia dewasa. ${ }^{1}$

Pendidikan keluarga adalah pendidikan individu yang kelak menentukan corak kepribadian para anggota keluarganya. Keluarga merupakan tempat pertumbuhan anak yang pertama dimana anak mendapatkan pengaruh dari anggotanya pada masa yang sangat penting dan paling kritis, yaitu tahun-tahun pertama dalam kehidupannya. Segala input yang masuk pada pribadi anak di awal kehidupannya yang melekat kuat dan menjadi dasar kepribadian yang disandang oleh anak. Berkaitan dengan hal itu, Hasan Basri mengutip pendapat Tallco Parson bahwa sosialisasi, seperti belajar berlangsung terus sepanjang hidup namun, prosesnya paling dramatis jika dilihat kaitannya dengan anak. ${ }^{2}$

Keunggulan pendidikan keluarga yang bernilai penting bagi kedewasaan anak tersebut dapat dipahami, karena keluarga memiliki potensi natural sebagai media produktif dan ia juga merupakan aktualisasi religius, rekreatif, edukatif, sosial, dan protektif. $^{3}$

Anak merupakan cikal bakal yang diharapkan tumbuh dan berkembang menjadi generasi penerus perjuangan para pendahulunya. ${ }^{4}$ Tapi tidak jarang dalam proses dan perkembangannya, seorang anak mengalami gangguan yang tidak diketahui dari mana datangnya, sehingga tidak mustahil perkembangannya terhambat, bahkan terhambat sama sekali. Kegagalan disini bukan semata-mata berasal dari anak karena ketidakmampuan merespon transformasi keilmuan tapi cenderung merujuk pada sistem kependidikannya. Terutama dalam pendidikan keluarga, hal ini kaitannya dengan keluarga guru seperti yang kita telah ketahui bahwa guru adalah sosok pendidik yang menjadi panutan bagi anaksiswinya di sekolah. Sedangkan dalam keluarga ia menjadi panutan berkewajiban mendidik anaknya.

Kondisi yang demikian berpengaruh terhadap pola pendidikan anak dalam keluarga, utamanya pendidikan agama yang berlangsung dalam keluarga. Terutama dalam hal

\footnotetext{
${ }^{1}$ Fuadudin, Pengasuhan Anak Dalam Keluarga Islam (Lembaga Kajian Agama dan Jender, 1999), hal.5.

2 Philip Robinson, alih bahasa, hasan basari, Beberapa Persepektif Sosiologi Pendidikan (Jakarta Rajawali Prees,1986), hal.58.

${ }^{3}$ Fuadudin, Pengasuhan Anak Dalam Keluarga Islam (kerjasama antara lembaga kajian agama dan gender, solidaritas perempuan dan the asian foundation, 1991), hal. 16.

${ }^{4}$ Zakiah daradjat, Ilmu Jiwa Agama (Jakarta:Bulan Bintang,1970), hal. 109-111.
} 
pendidikan salat, karena salat adalah kewajiban bagi umat Islam dan hal tersebut harus kita perkenalkan pada anak-anak sejak usia dini. Pada masa itu, anak berada dalam keadaan yang sangat peka terhadap stimulus internal dan eksternal, dan semua perkembangan anak mulai terbentuk dan cenderung menetap sampai usia dewasa. Jika salat tidak diperkenalkan dan ditanamkan sejak dini atau salah dalam penyampaiannya kepada anak, maka anak akan acuh tak acuh terhadap salat yang notabene salah satu kewajiban yang harus dijalankan oleh umat Islam.

Disamping itu dalam menanamkan pendidikan salat kepada anak diperlukan metode yang tepat, karena keberhasilan dalam pendidikan, khususnya dalam proses belajar tidak terlepas dari metode yang digunakan dan materi yang akan disampaikan. Metode ini sangat penting untuk mencapai tujuan yang telah ditetapkan. Tanpa metode suatu materi tidak dapat berproses secara efektif dan efisien untuk mencapai tujuan dari pendidikan. Metode tidak berarti tanpa didukung komponen yang lain. Metode hanya penting dalam hubungan dengan segenap komponen lainnya, seperti: tujuan materi, anak didik, pendidik dan situasi. ${ }^{5}$

Pada masa sekarang ini masih banyak orangtua yang kurang paham terhadap perkembangan yang dimiliki oleh anaknya. Metode yang ditunjukkan hanya pada ranah kognitif saja. Padahal anak pada usia 5-10 tahun belum memiliki konsep yang jelas dalam hal pengetahuan. Mengingat pentingnya pendidikan salat pada anak usia 5-10 merupakan fondasi dari agama dan kepribadiannya, maka memahami karakteristik anak menjadi sangat penting bagi orangtua untuk membantu anak dalam proses perkembangannya apabila menginginkan generasi yang mampu mengembangkan diri secara optimal. Metode pengajaran yang diterapkan perlu disesuaikan dengan karakteristik anak. Penggunaan metode yang tepat dan sesuai dengan karakter anak akan dapat membantu kemampuan anak secara optimal, yang akan berakibat dengan tumbuhnya sikap dan perilaku positif bagi anak.

Adapun ditetapkannya Padukuhan, Kadipolo, Sendangtirto, Berbah, Sleman, Yogyakarta sebagai lokasi penelitian didasarkan pada Padukuhan Kadipolo Sendangtirto Berbah Sleman ini terdiri dari dua Dusun yaitu Dusun Kadipolo dan Dusun Babadan. Di kedua dusun tersebut terdapat warga yang berprofesi sebagai seorang guru di Taman Kanak-Kanak, Sekolah Dasar, Sekolah Menengah Pertama, Sekolah Menengah Atas dan Sekolah Menengah Kejuruan. Adapun data warga yang berprofesi sebagai guru yang diterima oleh penulis dari Padukuhan Kadipolo, Sendangtirto, Berbah, Sleman adalah sebagai berikut: Dusun Kadipolo, terdapat warga yang berprofesi menjadi guru sebanyak 28 (dua puluh delapan) warga, dan

\footnotetext{
5 Zuharini dkk, Metode Khusus Pendidikan Agama (Surabaya : Usaha Nasional 1983), hal.79.
} 
yang mempunyai anak usia 5-10 tahun ada 8 (delapan) warga. Sedangkan di Dusun Babadan, data yang penulis peroleh mengenai warga yang berprofesi sebagai guru sebanyak 9 (sembilan) warga, dan yang mempunyai anak usia 5-10 tahun tidak ada. Jadi keseluruan warga yang beragama Islam yang berprofesi menjadi guru di Padukuhan Kadipolo berjumlah 37 (tiga puluh tujuh) warga dan yang mempunyai anak berusia 5-10 tahun sebanyak 8 (delapan) warga.

Dari bekal data yang diperoleh diatas maka penulis tertarik untuk meneliti Padukuhan Kadipolo ini, tentang bagaimana keluarga guru menerapkan metode pendidikan salat pada anak-anaknya yang berusia 5-10 tahun. Karena mayoritas warga di Padukuhan Kadipolo yang berprofesi sebagai guru beragama Islam. Mereka sangat memperhatikan anak-anak mereka dalam hal beribadah, terutama ibadah salat dan berusaha mengembangkan potensi anaknya bedasarkan nilai-nila Islam dan tuntunan Nabi Muhammad SAW.

\section{PEMBAHASAN}

Pendidikan keluarga adalah pendidikan individu yang kelak menentukan corak kepribadian para anggota keluarganya. Keluarga merupakan tempat pertumbuhan anak yang pertama dimana anak mendapatkan pengaruh dari anggotanya pada masa yang sangat penting dan paling kritis, yaitu tahun-tahun pertama dalam kehidupannya. Segala input yang masuk pada pribadi anak diawal-awal kehidupannya yang melekat kuat dan menjadi dasar kepribadian yang disandang oleh anak. Berkaitan dengan hal itu, Hasan Basri mengutip pendapat Tallco Parson bahwa sosialisasi, seperti belajar berlangsung terus sepanjang hidup namun, prosesnya paling dramatis jika dilihat kaitannya dengan anak. ${ }^{6}$

Disamping itu dalam menanamkan pendidikan kepada anak diperlukan metode yang tepat, karena keberhasilan dalam pendidikan, khususnya dalam proses belajar tidak terlepas dari metode yang digunakan dan materi yang akan disampaikan. Metode ini sangat penting untuk mencapai tujuan yang telah ditetapkan. Tanpa metode suatu materi tidak dapat berproses secara efektif dan efisien untuk mencapai tujuan dari pendidikan. Metode juga tidak berarti tanpa didukung komponen yang lain.

Pada masa kini masih banyak orangtua yang kurang paham terhadap perkembangan yang dimiliki oleh anaknya. Metode yang ditunjukkan hanya pada ranah kognitif saja. Padahal anak pada usia 5-10 tahun belum memiliki konsep yang jelas dalam hal pengetahuan.

Mengingat pentingnya pendidikan salat pada anak usia 5-10 merupakan fondasi dari agama dan kepribadiannya, maka memahami karakteristik anak menjadi sangat penting bagi

\footnotetext{
${ }^{6}$ Philip Robinson, Beberapa Persepektif Sosiologi Pendidikan, Jakarta: Rajawali Prees,1986.
} 
orangtua untuk membantu anak dalam proses perkembangannya apabila menginginkan generasi yang mampu mengembangkan diri secara optimal. Metode pengajaran yang diterapkan perlu disesuaikan dengan karakteristik anak. Penggunaan metode yang tepat dan sesuai dengan karakter anak akan dapat membantu kemampuan anak secara optimal, yang akan berakibat dengan tumbuhnya sikap dan perilaku positif bagi anak dan dapat mencapai tujuan yang di harapkan, dengan demikian pembelajaran itu dapat dikatakan berhasil atau sukses.

Berikut ini adalah gambaran dari proses pembelajaran yang dilakukan keluarga guru dengan menggunakan metode tertentu sebagai berikut:

\section{Cara Pengajaran Salat pada Anak-Anak}

Untuk menjelaskan materi pembelajaran tertentu membutuhkan penjelasan terutama untuk menyampaikan penekanan atau isi dari materi yang akan disampaikan. Dalam pembelajaran materi ibadah salat, pada tahap awal orangtua menjelasakan bagaimana salat itu di lakukan. Berikut ini hasil wawancara yang dilakukan peneliti kepada beberapa keluarga guru sebagai berikut:

Berikut adalah hasil wawancara yang dilakukan oleh peneliti kepada Ibu Enggar, beliau menuturkan: ${ }^{7}$

"Terus terang saya tidak mengajarkan anak saya salat karena saya menyekolahkan anak saya di TK IT dan anak saya, saya lanjutkan di SD Muhammadiyah itu semua saya lakukan agar anak saya mendapat pondasi pelajaran PAI, saya dirumah hanya menambahkan ketika anak saya tidak tau atau melakukan kesalahan saat salat".

Begitu pula dengan penuturan Ibu Tentrem: ${ }^{8}$

"Saya tidak mengajarkan dirumah karena waktunya yang kurang buat anak saya. Dari situ anak saya, saya sekolahkan di TK IT dari sekolah itu dia sudah diajarkan salat dan saya dirumah hanya mengulas pelajaran yang di dapat dari sekolah dan menambahkan dan membenarkan bacaan dan gerakan salat yang salah".

Sementara Ibu Rini berbeda, beliau menuturkan: 9

"Saya mengajak anak saya salat berjamaah dan mengenalkan salat itu begini, gerakannya begini dan saya menyekolahkan anak saya di SD IT disitu dia juga mendapat bekal tentang pelajaran salat, dan ketika berjamaah saya melihat perkembangan anak saya dari situ saya bisa lihat ada nggak kesalahan kalau ada langsung saya benarkan".

Dari pertanyaan yang diajukan, diperoleh peryataan responden yang terdiri dari: Ibu Tentrem, Ibu Enggar, dan Ibu Rini, peneliti dapat menyimpulkan bahwa pendidikan yang dilakukan mereka terutama pendidikan salat dalam keluarga mereka kurang berperan disebabkan karena keterbatasan waktu dan aktifitas diluar rumah. Mereka hanya mengandalkan pendidikan yang

\footnotetext{
${ }^{7}$ Wawancara dengan Ibu Enggar, guru di TK AL Amni Gowongan Kidul Jetis 3 417. Pada tanggal 5 Desember 2018.( putra yang bernama Rifan Maulana usia 10 tahun)

8 Wawancara dengan Ibu Tentrem, guru di SD Baran Patuk. Pada tanggal 5 Desember 2018.(putra yang bernama Andreas usia 8 tahun)

${ }^{9}$ Wawancara dengan Ibu Rini, guru TK ABA Rejowinangun Kota Gede. Pada tanggal 5 Desember 2018.( putrid yang bernama Wulan Suci usia 10 tahun)
} 
didapat dari sekolah tapi dalam keluarganya hanya mengulas jika ada waktu luang. Putra mereka yang baru berusia 8-10 tahun, masih sangat dini kalau mereka hanya mengandalkan pendidikan dari sekolah saja maka akan kurang pendidikan yang diperoleh putra mereka baik pendidikan umum ataupun pendidikan salat. Hal ini sangat berkaitan dengan peran keluarga sebagai media produktif dan ia juga merupakan aktualisasi religius, rekreatif, edukatif, sosial, dan protektif.

Dalam pendidikan salat yang terjadi dalam keluarga subyek-subyek diatas, terlihat bahwa yang terjadi hanyalah fungsi monitoring atas edukasi yang diperoleh bukan dari keluarga, melainkan dari sekolah. Padahal keluargalah yang berperan penting dalam pengasuhan anak. Alangkah lebih baik jika mereka memberikan pendidikan dalam keluarga dan mengulas pendidikan yang didapat putranya di sekolah, serta beliau juga mengajak putranya untuk salat berjamaah bersama, agar dapat melihat perkembangan putranya terutama dalam pendidikan salat. Karena salat adalah kewajiban bagi umat Islam, maka sejak dini harus diajarkan dan ketika anak sudah mendapat pendidikan salat di sekolah maka orangtua juga harus mengulasnya di rumah agar tidak lupa.

Selain itu, metode mengulang kembali ini pun juga merupakan ajang aktualisasi religiusitas keluarga yang dengan kata lain adalah ciri religius keluarga terbentuk dari awal dan semua anggotanya merasa puas akan hal tersebut. Fungsi rekreatif juga berjalan dengan baik, karena ini merupakan ajang berkumpul dengan anggota keluarga secara lengkap sehingga mampu melekatkan kehangatan keluarga. Sedangkan fungsi edukatif tidak hanya semata-mata dilaksanakan di sekolah atau lembaga pendidikan tertentu, karena lembaga pendidikan yang paling efektif adalah keluarga, hal ini akhirnya membentuk keluarga dengan fungsi sosial yang seimbang dan dapat menjadi ajang proteksi dari masing-masing anggota keluarga untuk menghindarkan anggota-anggotanya dari pengaruh buruk, salah satu caranya adalah dengan saling mengingatkan.

Dari penuturan Ibu Rini dapat peneliti simpulkan bahwa pendidikan yang Ibu Rini terapkan pada anaknya dalam keluarga cukup baik karena kita melihat anak usia 5-10 tahun itu adalah masa dimana anak mendapat perhatian yang lebih terutama dalam pendidikan. Apalagi bila dikaitkan dengan pendidikan salat karena salat harus diterapkan sejak dini. Sesuai dengan teori yang peneliti pahami bahwa anak usia 1 bulan -7 tahun itu anak mulai dikenalkan dengan agamanya dan kewajiban dari agamanya agar ketika dewasa ia tidak kesulitan dalam pengenalan agama.

Berangkat dari hal tersebut, peneliti dapat katakan bahwasannya pendidikan yang Ibu Rini terapkan kepada putranya cukup baik karena disamping Ibu Rini mempunyai kesibukkan 250 | IQ (Ilmu Al-qur'an): Jurnal Pendidikan Islam | Volume 1 No.02 2018 
sebagai seorang guru dia mempunyai waktu juga untuk anaknya dalam pengawasan terhadap pendidikan terutama pendidikan salat. Karena salat adalah kewajiban bagi setiap umat Islam. Dari pernyataan itu beliau sangat memperhatikan pendidikan salat anaknnya dan sangat memperhatikan perkembangan dari putranya terutama dari pendidikan salat, disamping itu kedekatan dalam keluarga juga dapat mewujudkan keluarga yang harmonis. Maka disini sangatlah penting perhatian dan dukungan orangtua agar anak bisa berkembang menjadi lebih baik ke arah yang lebih positif. Bila melenceng kearah yang negatif maka orangtua juga yang akan kerepotan, maka tanamkanlah pendidikan salat sejak usia dini agar kelak dia tahu akan kewajibannya dan menjadi orang yang baik dan bertakwa pada Tuhannya.

Dalam penelitian lapangan yang dilakukan oleh peneliti ini tampak bahwa diantara respoden kurang memerhatikan pendidikan salat anaknya. Hal ini dapat dilihat dari wawancara yang dilakukan peneliti, responden hanya mengandalkan pendidikan yang didapat dari sekolah saja peran mereka dalam pendidikan salat dalam keluarga sangat minim. Padahal perhatian dan bimbingan orangtua sangat berpengaruh besar dalam pembelajaran yang berlangsung dalam keluarga. Karena perhatian dan bimbingan orangtua sangat berpengaruh besar dalam pendidikan anak dalam keluarga dan akan bisa menjalin hubungan yang harmonis dengan putra-putri mereka dari situlah pendidikan keluarga akan mudah diterima oleh anak terutama pendidikan keagamaannya.

\section{Metode yang digunakan dalam Pengajaran Pendidikan Salat pada Anak}

Dalam memberikan atau mengajarkan suatu pelajaran harus menggunakan cara atau metode agar materi yang diberikan kepada anak dapat diterima dengan baik dan dapat berhasil. Metode juga sangat berperan penting untuk kelancaran dalam penyampaian materi karena dalam pembelajaran tanpa adanya metode bagaikan "nasi tanpa garam". Dalam hal ini kita dapat mengulas tentang metode apa yang dipakai oleh para orangtua untuk menyampaikan materi pendidikan salat terutama dalam pendidikan dalam keluarga.

Berikut ini hasil wawancara yang dilakukan peneliti kepada Ibu Tentrem sebagai berikut: ${ }^{10}$

"Saya memberikan contoh dan pembisaaan ya mas karena dengan memberi contoh dan pembisaaan dengan salat bareng atau jamaah maka anak bisa meniru gerakan saya dan perpikir "o, ibu salat maka aku juga harus salat" dan dengan contoh itu ya mas maka anak itu bisa melihat dan mempraktekkan langsung begitu mas dan saya membisakannya itu dengan salat tepat waktu dan membiasakan agar salat setiap saat". Lain halnya dengan peryataan Bapak Jamhari: ${ }^{11}$

\footnotetext{
${ }_{10}$ Wawancara dengan Ibu Tentrem, guru di SD Baran Patuk. Pada tanggal 5 Desember 2018. .(putra yang bernama Andreas usia 8 tahun)

11 Wawancara dengan Bapak Jamhari, guru SD Gayam Harjo, pada tanggal 8 Desember 2018.(putra yang bernama Yunantor Yukarnain usia 9 tahun)
} 
"Saya menggunakan metode contoh, keteladanan dan memberi nasihat karena metode itu saya dapat turun temurun dari bapak saya maka saya juga terapkan dengan anak saya itu semua saya lakukan dulu agar anak saya melihat saya dulu kebisaaan saya dan setelah mereka melihat maka anak saya saya suruh. Dengan metode ini anak saya bisa meniru saya mas".

Pernyataan dari ibu Tentrem tersebut senada dengan respoden lainya tapi berbeda dengan Bapak Jamhari. Dari penjelasan beliau diatas dapat kita lihat betapa beliau sangat memperhatikan metode guna mendukung pemberian stimulus atau rangsangan untuk pembelajaran yang dilakukannya agar dapat diterima oleh anaknya. Beliau menggunakan metode mencontoh dan pembisaaan, menurut peneliti metode yang dipakai beliau sangat efektif untuk anak usia 5-10 tahun.

Mengingat anak merupakan cikal bakal yang diharapkan tumbuh dan berkembang menjadi generasi penerus perjuangan para pendahulunya, maka metode itu yang peniliti rasa paling tepat diterapkan kepada anak usia 5-10 tahun. Jika tidak dibiasakan akan cepat lupa dan anak tidak bisa melakukan salat sendiri jika tidak dicontohkan atau tidak ada bimbingan dari orangtuanya. Hal ini didasari atas kemampuan anak tentang konsep dan gambaran pada anak dalam usia 5 - 10 tahun belum terbentuk sempurna, sehingga pendidikan contoh dan pembiasaan menjadi tepat dilaksanakan.

Sedangkan fungsi dari keteladanan adalah sebagai salah satu cara pembentukan konsep yang sesuai dengan tahapan perkembangan usia anak masa itu. Cerita, dongeng,yang kemudian diakhiri dengan nasihat akan sangat membantu orangtua dalam menanamkan konsep mudah akan pentingnya salat. Ketika anak umur 5-10 tahun tidak dibiasakan dan dicontohkan sejak dini dalam pengenalan pendidikan salat, mereka akan kesulitan bila sudah beranjak dewasa. Karena salat adalah salah satu kewajiban bagi kita umat Islam, maka sewajarnya salat di terapkan sejak dini agar mereka mengenal salat sejak dini dan sudah terbiasa. Dan dengan metode pembisaaan ini mereka bisa terbiasa melakukan salat agar di kemudian hari bila mereka tidak menjalankan salat terlihat ada yang kurang dalam dirinya.

Berbeda dengan yang diutarakan oleh Bapak Jamhari peneliti menemukan hal lain, yaitu menggunakan metode yang turun-temurun dari ayahnya yaitu metode contoh, keteladanan dan memberi nasihat. Hal ini beliau lakukan karena metode yang digunakan oleh ayahnya untuk beliau diwaktu masih anak-anak dinilai berhasil dari situ beliau menggunakan metode itu menurut peneliti tidak menyalahkan beliau tapi dalam hal ini karakter dari anak zaman sekarang dan zaman dulu berbeda, karakter anak pada zaman sekarang lebih maju dan berpikirnya panjang karena pengaruh dari lingkungan dan zaman yang modern ini tapi anak pada zaman dulu ketika orangtua memerintahkan sesuatu, anak relatif tidak melawan 
walaupun hal tersebut mungkin saja salah atau kurang tepat dan bahkan bisa saja tak bermanfaat bagi dirinya dan tanpa berpikir panjang langsung dilaksanakannya perintah tersebut.

Maka disitulah perlu adanya perkembangan-perkembangan metode agar tidak monoton dan sesuai perkembangan zaman. Terlihat dari metode yang digunakan oleh mereka itu sudah sangat mewakili, karena kebanyakan dari responden menggunakan metode yang sama. Karena dimata responden anak usia 5-10 itu metodenya adalah mencontoh, pembisaaan, mempraktekkan dan menghafal karena dengan metode itulah anak usia 5-10 tahun bisa mengeti. Dan anak usia 5-10 tahun menurut peneliti baru dikenalkan dengan keagamaannya dan dicontohkan bagaimana salat itu dilaksanakan dan untuk menjalankan itu mereka tidak bisa dilepas, seperti orang dewasa mereka harus diawasi terus menerus dan dibimbing agar kelak ketika dewasa mereka sudah terbiasa dengan salat lima waktu. Dan peneliti juga melihat dari pendapat dari Abdul Mujib yang menyatakan bahwa anak umur 1 bulan - 7 tahun itu juga dapat disebut fase kanak-kanak (al-thifl) yang disini ia menyebutkan bahwasanya anak umur 1 bulan hingga 7 tahun itu baru dikenalkan dengan doktrin aspek-aspek keagamaan, terutama dengan keimanan dari situlah anak usia 5-10 tahun tak bisa dibiarkan tanpa pengawasan dari orangtua karena anak umur 5-10 tahun perlu bimbingan yang intensif agar bisa memahami pengajaran yang dilakukan orangtuanya terutama dalam hal ibadah salat.

Dari wawancara yang dilakukan peneliti kepada responden kebanyakan dari mereka menggunakan metode pembiasaan dan contoh karena dinilai dengan metode pembiasaan anak akan terbiasa salat dan ketika dia tidaka melaksanakan salat mereka melihat ada yang janggal dan dengan pembiasaan sejak dini diwaktu ia dewasa akan terbiasa dan bukanlah barang baru salat itu. Serta dengan metode contoh mereka bilang lebih baik juga karena anak usia 5-10 tahun kalau tidak dicontohkan tidan akan bisa jalan sendiri mereka adalah anak kecil bukan orang dewasa. Maka dinilai dengan mencontoh mereka bisa lebih cepat mengerti tentang gerakan-gerakan salat yang diajarkan oleh orangtuanya. Dalam hal ini dikuatkan denga teori yang di kemukakan oleh Ahmad Tafsir dalam mengajarkan pendidikan salat dengan beberapa metode dengan pembiasaan, mencontoh, motivasi atau dorongan, dengan ini peneliti menyatakan metode yuang digunakan para orangtua ada relevansinya dengan teori yang peneliti pakai.

\section{Penerapan Metode yang digunakan dalam Mengajarkan Anak Salat}

Kita ketahui bawasannya bila kita sudah menggunakan metode dalam pembelajarannya kita juga harus menerapkannya dalam kegiatan pembelajarannya agar dapat diketahui apakah 
metode itu dapat berjalan sesuai yang kita harapkan atau tidak, dan dapat mengetahui sejauh mana metode yang terapkan pada anak dapat dipahami oleh anak. Dalam hal ini perlunya mengetahui penerapan metode yang digunakan oleh keluarga guru dalam mendidik para putra-putrinya.

Berikut ini hasil wawancara peneliti dengan Bapak Gatot Wasito sebagai berikut: ${ }^{12}$

"Mengajak anak saya kemasjid kalau saya pas ada dirumah dan mengingatkan agar selalu salat dan kalau pas saya dirumah tak ajak salat bareng mas agar anak jadi biasa”.

Wawancara yang saya lakukan kepada putra bapak Gatot yang bernama Doni Setiawan sebagai berikut: ${ }^{13}$

Peneliti: Doni sering ngnggak di ajak ke masjid sama bapak?

Doni : Iya Mas, kalau bapak ada dirumah pasti diajak dan di suruh.

Peneliti:apakah adik sering di ingatkan untuk salat?

Doni : Sering Mas, saya baru asik main itu diingetin "Don salat dulu".

Peneliti:adik paling sering di ajak salat jamaah pada waktu salat apa?

Doni :Pas waktu salat magrib karena jam segitu bapak sering ada dirumah.

Lain halnya dengan penuturan yang disampaikan oleh Ibu Tentrem sebagai berikut: ${ }^{14}$

"Saya ajak anak saya salat berjamaah dirumah waktu salat magrib dan isya karena saya pas waktu itu saya bisa salat bersama dengan anak saya dan melihat perkembangan anak saya dan saya bisa melihat gerakan dan bacaan anak saya ketika sedang salat terus kalau ada yang salah tak benarkan kalau udah selesai salat gitu mas".

Dan wawancara yang peneliti lakukan pada putra Ibu Tentrem yang bernama Andreas sebagai berikut: ${ }^{15}$

Peneliti: Apakah adik di suruh salat sama ibu?

Andres: Iya mas

Peneliti: Adik sering di suruh ke masjid?

Andres: Iya Mas, pas waktu salat maghrib mas.

Peneliti: Adik sering di ajak berjamaah bersama ibu sama bapak?

Andres: Iya Mas.

Dari peryataan Bapak Gatot Wasito dapat dikatakan bahwasannya penerapan metode yang beliau terapkan pada putra beliau sudah berjalan, dapat dikatakan berjalan dengan baik. Dengan contoh dan pembiasaan yang beliau lakukan maka anak akan terbiasa tapi dalam hal penerapan metode itu beliau hanya bisa melakukan ketika beliau tidak sibukk atau sedang dirumah. Perlu kita ketahui, jika menggunakan metode pembisaaan dan contoh beliau harus

\footnotetext{
12 Wawancara dengan Bapak Gito Wasito, guru di SMP Muhammadiyah Wonosari. Pada tanggal 5 Desember 2018.(putra yang bernama Doni Setiawan usia 9 tahun)

${ }^{13}$ Wawancara dengan Doni putra Bapak Gatot. Pada tanggal 6 Desember 2018.

${ }^{14}$ Wawancara dengan Ibu Tentrem, guru di SD Baran Patuk. Pada tanggal 5 Desember $2018 . \quad$ ( putra yang bernama Andreas usia 8 tahun)

${ }^{57}$ Wawancara dengan Andres putra Ibu Tentrem. Pada tanggal 7 Desember 2018.
} 
membiasakan diri juga salat tepat waktu agar anak bisa meniru kebisaaan dan mencontoh yang dilakukan oleh orangtuanya.

Namun jika sering pergi otomatis dalam hal ini anak tidak bisa mencontoh pembisaaan yang beliau lakukan. Maka dalam hal ini perlunya kehadiran orangtua dalam menerapkan metode tersebut agar anak bisa meniru kebisaaan yang dilakukan oleh orangtuanya. Dan beliau tidak bisa melihat perkembangan dari penerapan metode yang beliau terapkan dalam pendidikan salat, serta beliau tidak bisa melihat apakah metode ini bisa diterapkan pada anak saya atau tidak. Maka dalam penerapan suatu metode harus ada pengawasan yang terus-menerus dari orangtua agar dapat mengetahui perkembangan putranya dan apakah metode ini masih relevan atau tidak diterapkan pada putranya. Karena metode itu akan menentukan keberhasilan dari suatu pembelajaran. Apalagi dalam hal pendidikan salat karena salat adalah kewajiban bagi umat Islam maka untuk mengajarkanya kita harus tepat agar mereka bisa memahami pendidikan salat ini dengan baik dan sungguh-sungguh. Karena kalau salah metode maka anak ini akan bingung dan tidak mau melaksanakan perintah yang diberikan oleh orangtuanya. Maka apalagi dalam hal ibadah salat bila sampai salah metode dalam pembelajarannya, anak akan terkena celaan dan akan terpengaruh kepada hal yang negatif.

Lain halnya yang diterapkan oleh Ibu Tentrem beliau menerapkan metodenya dengan kehadiran dan pendampingan beliau setiap saat dan setiap waktu. Sehingga beliau bisa memantau perkembangan anaknya terutama dalam pendidikan salat dan memantau apakah metode yang saya pakai masih relevan atau tidak dengan perkembangan anak saya, jika tidak maka akan saya ganti dengan metode yang baru dan lebih bisa diterima oleh putranya. Berbeda dengan Bapak Gatot kalau beliau tak bisa memantau apakah metode nya masih relevan atau tidak digunakan oleh putranya. Dalam hal ini peneliti lebih tertarik pada metode yang diterapkan oleh Ibu Tentrem, karena beliau bisa memantau perkembangan penerapan metode yang beliau gunakan pada anaknya. Dan beliau bisa mengkompilasikan atau menerapkan dengan metode lainya. Dan keuntungan bila penerapan metode yang dilakukan pada anak terus di awasi. Beliau bisa melihat perkembangan dari putranya ketika mengajarkan pendidikan itu dengan suatu metode.

Bedasarkan observasi, pengamatan ${ }^{16}$ yang dilakukan peneliti yang dikuatkan oleh pernyataan dari putra Bapak Gatot Wasito dan Ibu Tentrem peneliti menyimpulkan bahwa metode yang diterapkan mereka kepada putranya benar-benar dilakukan oleh mereka dan juga diterapkan pada putranya, putranya pun dapat menerima penerapan metode yang diterapkan oleh

\footnotetext{
${ }^{16}$ Observasi yang dilakukan pada tanggal 6 Desember 2018.
} 
mereka, maka peneliti dapat katakan bahwasannya penuturan yang dilakukan mereka pada waktu peneliti wawancarai dan dengan dibandingkan dengan hasil observasi dan wawancara pada putranya dapat disimpulkan bahwa keluarga mereka memang menggunakan metode contoh dan pembisaaan. Maka dapat disimpulkan bahwa perkataan mereka sesuai dengan perkataan putranya dan pernyataan mereka tadi tidak mengada-ngada tetapi benar dilakukannya.

\section{Problematika yang Dihadapi Orangtua dalam Pelaksanaan Metode Pendidikan Salat}

Dalam penerapan suatu pembelajaran didalam keluarga atau dimanapun kita memerlukan cara agar pembelajaran yang kita lakukan itu dapat mudah diterima oleh anak. Tapi beda halnya dengan metode, kalau metode itu tidak sesuai dengan karakteristik anak maka tujuan dari pembelajaran itu tidak akan tersampai kepada anak, itu bisa dinamakan hambatan yang berasal dari metode. Hambatan tidak datang dari metode melainkan juga datang dari luar misalnya dari anak itu sendiri, lingkungan sekitar.

Memang tidak bisa dipungkiri kalau dalam suatu pembelajaran yang kita lakukan pada anak itu pasti ada hambatan, tidak mulus begitu saja untuk mencapai tujuan yang kita inginkan. Hambatan-hambatan yang ada adalah sebagi introspeksi diri kita bukan sebagai masalah bagi diri kita selaku orangtua dalam mengajarkan suatu pendidikan karena kita bisa mengetahui bahwasannya kita sudah mengatahui hambatan itu kita dapat memperbaiki dengan cara kita belajar ataupun cara penyamaian kita kepada putra-putri kita.

Seperti yang dijelaskan diatas tadi hambatan datangnya tidak dari orangtua yang menerapkan metode tertentu melainkan kemungkinan dari putra-putri mereka. Hambatan dari putra-putri inilah yang harus kita mengerti atau pahami, sehingga kita dapat mengintropeksi dan dapat menyesuaikan kondisi kita dengan pitra-putri kita agar dalam proses pembelajaran dapat berlangsung dengan lancar.

Berikut ini gambaran mengenai hambatan penerapan metode pendidikan salat pada keluarga guru di Padukuhan, Kadipolo, Sendangtirto, Berbah, Sleman, Yogyakarta.

Bedasarkan observasi yang peneliti lakukan untuk mengetahui hambatan dari penerapan metode yang keluarga guru lakukan kepada para putra-putrinya, hambatan yang paling besar itu ketika putra-putri mereka sedang asik bermain. Disini peneliti melihat sendiri hambatanhambatan yang dihadapi orangtua seperti halnya yang berikut ini ketika sore hari mereka pada berkumpul dengan teman-temannya mereka bermain sepak bola yang ada di samping desyang bermain di tempat tetangganya yang ada di sebelah seperti putra Bapak Jamhari yang bermain dengan putra Ibu Tentrem yang rumahnya saling berdekatan mereka bermain di waktu pulang sekolah sampe sore. 
Mereka sering lupa waktu sampai dicari oleh oranga tuanya. seperti yang dilakukan oleh Ibu Zulis Sudarojah ketika itu putrinya sedang asik bermain bersama dengan tetangga sebelah rumah yaitu mainan monopoli dan pada waktu itu sudah waktunya salat Ashar anaknya tidak pulang dan Ibu Zulis membawa kemoceng dan menghampiri anaknya: ${ }^{17}$

Ibu Zulisti : :Ayu pulang dulu salat asar.

Ayu :Bentar bu nanggung.

Ibu Zulisti :Ayo pulang dulu, apa milih tak pukul pakai kemoceng apa salat dulu, cuma bentar juga paling lima menit ayo pulang dulu salat.

Ayu $\quad$ : Iya bu (dia langsung lari pulang dan salat ashar, hampir lima menit dia datang lagi).

Ibu Zulisti :Cepetkan ming lima menit aja kok perlu dibawakan kemoceng dulu hehehehehe. Salat itu wajib Yu kalau tidak salat dosa"

Itu tadi observasi yang peneliti lakukan pada keluarga Ibu Zulis dan peneliti juga mewawancarai Ibu Zulis yang hasilnya sebagai berikut: ${ }^{18}$

"Anak saya ini suka ngeyel waktu disuruh salat tepat waktu mas karena dia sedang main dan saya juga berpatokan hadis Nabi itu mas kalau anak 7 tahun nggak solat ya disuruh kalau 10 tahun tak hukum yg mendidik, ya alhamdulilah anak saya dari usia 7 tahun sudah salat mas walaupun harus pake diingatkan ya maklum mas anak-anak, kalau dilepas gt aja ya malah lupa makanya perlu adanya didikan mas biar nanti jadi kebiaasaan".

Pernyataan Ibu Zulisti ini senada dengan responden yang lain seperti dengan Bapak Gatot Wasito juga berpendapat: ${ }^{19}$

"Kendalanya karena anaknya main mas sama temennya dan kalau anak-anak lelah atau capek itu mereka mandi langsung tidur mau dibangunin kasihan anaknya mereka capek saya lihat kasihan gitu mas kalau tidurnya pulesss ya namanya anak-anak mass heheheheh"

Dari pemaparan diatas maka dapat dikatakan kesulitan yang dihadapi oleh para orangtua ketika menerapkan metode yang beliau pakai adalah terletak pada putranya bukan dari metodenya atau orangtuanya. Kesulitan-kesulitan itu tidak hanya dari dalam diri putranya tapi juga dari beberapa faktor yang diantaranya adalah dari faktor lingkungan karena anak-anak juga terpengaruh oleh lingkungan setempat tempat mereka bergaul dan bersosialisasi dengan masyarakat luar dengan contoh ketika mereka asik bermain dengan teman sebaya atau main di tempat tetangganya maka mereka juga terpengaruh ketika temannya tidak melaksanakan salat tepat waktu, disinilah kesulitan dalam penerapan metode yang dipakai oleh orangtua kepada putra-putrinya juga timbul. Tapi ada juga faktor yang ditimbulkan dari diri anak itu

\footnotetext{
${ }^{17}$ Observasi pada keluarga Ibu Zulis tanggal 7 Desember 2018.

18 Wawancara dengan Ibu Zulisti Sudarojah, guru di MTsN Semanu Gunungkidul. Pada tanggal 8 Desember 2018.(putri yang bernama Ayu Mungtiyah Safitri usia 10 tahun)

${ }_{19}$ Wawancara dengan Bapak Gatot Wasito, guru SMP Muhammadiyah Wonosari. Pada tanggal 5 Desember 2018. ( putra yang bernama Doni Setiawan usia 9 tahun)
} 
sendiri yaitu ketika anak itu malas, kalau anak itu malas maka dia akan tidak memikirkan hal lain mereka hanya diam dan sibukk sendiri. Hal itu juga sangat menghambat penerapan dari metode tersebut. Dari beberapa faktor diatas itulah kesulitan-kesulitan yang hapir sama yang dihadapi orangtua ketika menerapkan metode tersebut, dan peneliti dapat kataka hasil wawancara yang saya lakukan kepada Ibu Zulis dan bapak Gatot Wasito tentang hambatan apa yang dihadapi ketika menerapkan metode pendidikan salat pada putra-putrinya yaitu karena anak males, ngeyel dan asik bermain, itu juga sependapat dengan responden lainnya itu benar karena peneliti bandingkan dengan hasil observasi yang peneliti lakukan dilapangan itu sesuai dengan pernyataan Ibu Zulis dan responden lainnya ternyata putra-putri mereka kalau sudah asik bermain dengan teman-temannya mereka lupa akan kewajibannya yaitu salat maka dalam hal ini pernyataan dan kenyataan yang terjadi tentang hambatan-hambatan yang dihadapi orangtua memang terjadi dilapangan.

Dan dibawah ini peneliti akan mencoba menguraikan beberapa faktor yang menghambat dalam penerapan metode pendidikan salat sebagai berikut:

\section{Acara hiburan televisi yang mengabaikan nilai-nilai pendidikan.}

Salah satu penyebab dari hambatan penerapan metode pendidikan salat dalam keluarga karena putra-putri mereka sedang menikmati acara hiburan di televisi yang sangat beragam dari acara anak-anak samapai acara orang dewasa, sehingga tidak mengherankan bila anak ketika sudah melihat acar televisi sudah melupakan semuanya. Maka dalam hal ini perlu adanya campur tangan orangtua dalam pengawasan menonton acara televisi untuk anak. Hal ini untuk menghindari dampak negatif yang ditimbulkan oleh acara televisi yang ditonton oleh anak karena lambat laun akan memengaruhi kepribadian anak.

\section{Lingkungan sekitar}

Kita tidak bisa pungkiri bahwa likungan adalah salah satu faktor yang sedikit banyak berpengaruh dalam perkembangan anak. Likungan yang baik akan membawa dampak baik pula kepada masyarakat yang ada didalamnya begitu pula sebaliknya. Walaupun anak lebih banyak menghabiskan waktu di dalam lingkungan keluarga, lingkungan adalah salah satu faktor yang harus dijadikan peringatan bagi orangtua agar selalu mengontrol pergaulan dari anaknya jangan sampai terjerumus ke dalam pergaulan yang negatif yang bisa menghancurkan perkembangan kepribadian anak.

Karena kita mengetahui perkembangan zaman sekarang ini yang penuh dengan pergaulan yang bebas, kita juga harus berhati-hati pada pergaulan kebudayaan yang berasal dari barat yang hampir memusnahkan kebudayaan kita sendiri yang penuh dengan adat, norma dan tata karma. 
Dimasa sekarang ini, unsur lingkungan mampu mengalahkan unsur dari keluarga sehingga mereka merasa gagal dalam menangani pendidikan anak mereka. Radio, televisi, koran majalah, telepon genggam, internet, merupakan sarana-sarana lingkungan yang membuat manusia terpengaruh anak usia 5-10 tahun sangat mudah terpengaruh dengan hal seperti itu. Kalau kita melarang anak kita untuk tidak menonton dan menggunakan hal seperti itu sama aja kita mengekang mereka dari kemajuan teknologi. Dalam hal ini akan berdapak pada psikologis anak. Dan kenyataan itu menuntut kita sebagai orangtua memberi sedikit kebebasan untuk anak agar mereka juga menikmati kemajuan teknologi dalam era ini. Tapi dalam memberi kebebasan itu kita juga harus mengawasi anak agar tidak terjerumus kehalhal negatif. Maka dalam hal ini perhatian orangtua sangat berpengaruh besar agar anak tidak terjerus dalam hal negatif.

\section{Dari diri anak.}

Penyebab juga dapat muncul dari dalam diri anak, anak di usia 5-10 tahun bukanlah manusia yang dapat sekali diberi pengertian langsung bisa mengerti tapi butuh pembiasaan. Ketika pembiasaan itu dilaksanakan terus menerus dari anak mungkin ada rasa bosan, jenuh, dan lelah. Disitulah kiat orangtua bagaimana agar anak ini tidak merasakan rasa itu dan mau menjalankannya, karena kalau tidak diberikan pada waktu yang dini maka anak akan tak terbiasa dengan ibadah salat dan nanti dikala dia dewasa akan kesulitan dalam pengenalan kwajiban yaitu kwajiban salat.

\section{Usaha yang dilakukan orangtua dalam mengatasi problematika pelaksanaan metode pendidikan salat}

Bedasarkan hasil observasi dan wawancara yang telah dilakukan oleh peneliti didapatkan hasil usaha-usaha yang dilakukan oleh orangtua dalam mengatasi problematika pelaksanaan metode pendidikan salat di Pedukuhan, Kadipolo, Sendangtirto, Berbah, Sleman, Yogyakarta adalah sebagai berikut:

Wawancara dengan Ibu Enggar, beliau menuturkan bahwa: ${ }^{20}$

"Dengan memberikan pengertian dan penekanan pentingnya salat itu bagi umat Islam, mengajak salat berjamaah dengan memberikan contoh salat itu gini lo dek, paling Cuma butuh waktu lima menit udah kalau main ditunda lima menitkan nggak papa. Dan saya juga usahakan salat saya tepat waktu agar anak saya niru saya mas biar kalau saya kandani (bilangi) ayo salat tepat waktu biar jawabnya iya gitu mas ,, nggak gini Ibu we salat nggak tepat waktu masak aku kudu tepat waktu hahahahahah biar nggak dibalik ma anak mas."

Oleh karena itu bedasarkan penuturan Ibu Enggar diatas dapat dipahami bahwa untuk mengatasi hambatan dari metode yang beliau terapkan dalam pendidikan salat pada putranya,

\footnotetext{
${ }^{20}$ Wawancara dengan Ibu Enggar, guru di TK AL Amni Gowongan Kidul Jetis 3 417. Pada tanggal 5 Desember 2018. ( putra yang bernama Rifan Maulana usia 10 tahun)
} 
beliau telah menemukan solusi dari kesulitan penerapan metode praktik yang beliau terapkan pada putranya yaitu dengan pengertian tentang penekanan pentingnya salat bagi umat Islam agar kelak di kehidupan yang akan datang bisa selamat dari siksa kubur. Beliau juga memberikan contoh tentang pendidikan salat pada putranya secara langsung. Solusi yang beliau lakukan untuk mengatasi hambatan yang beliau dapat ketika menerapakan metodenya. Hal itu dilakukan agar penerapan metode yang beliau terapkan pada putranya dapat berjalan dengan baik. Beliau lakukan ini agar anak bisa mengerti yang diajarkan oleh orangtuanya dan tidak mengalami kesulitan dalam memahami pendidikan yang beliau berikan pada putranya.

Senada dengan penuturan Ibu Enggar diatas maka Bapak Jarot Ansori juga berpendapat sebagai berikut: ${ }^{21}$

"Saya kasih pengertian tentang kewajiban umat Islam itu bagaimana harus menjalankan salat lima waktu dengan tepat waktu, itu saya terapkan pada putra saya mas karena denga itu anak bisa disiplin dalam menjalankan salat dan itu bisa membekalinya hingga dewasa juga kalau menjalankan salat tepat waktu gtu mas kalau saya heeeeee"

Sedangkan menurut Ibu Tentrem beliau berpendapat sebagai berikut: ${ }^{22}$

"Saya mengatasi permasalahan ini saya dengan pendekatan pada anak dan memberi pengertiyan pada anak kalau salat itu wajib kalau tidak melaksanakan dosa akan masuk nereka...........dan kalau masuk neraka itu disiksa dengan bagtu anak takut kalau masuk neraka maka melaksanakan salat. Dan salaing kerja sama anatara saya dan suami saya untuk mengatasi hal tersebut karena kalu tidak diatasi sedemikian dini nati takut saya, anak nggak mau salat gt massss heeeeeeeeee......."

Pendapat responden diatas juga di ikuti oleh Bapak Jamhari yang berpendapat sebagai berikut: ${ }^{23}$

"Usaha yang Saya lakukan deengan member pengertiyan, kita itu masi hidup lagi looo setelah ini kita mau milih surga pa neraka kalau pilih surga ya salatnya ditekun kan lagi jangan bolong-bolong dan saya tidak memberikan hukuman yang seperti dipukul saya paling dengan memberi pengarahan".

Dari pemaparan diatas dapat digarisbawahi bahwa responden sangat meperhatikan penerapan metode yang diterapkan pada putra mereka dikarenakan metode itu sangat penting dalam poses pembelajaran. Karena dengan metode itulah tujuan pembelajaran bisa disampaikan kepada putra-putri mereka. Dalam hal ini ketika penerapan metode dalam pendidikan dalam keluarga terutama dalam pendidikan salat menghadapi suatu kendala atau hambatan maka tujuan dari pembelajaran itu tidak akan tercapai semua.

\footnotetext{
21 Wawancara dengan Bapak Jarot Ansori, guru di SD Berbah Pandan Sari. Pada tanggal 8 Desember 2018 (putri yang bernama izki zanzabila usia 5 tahun)

${ }^{22}$ Wawancara dengan Ibu Tentrem, guru di SD Baran Patuk. Pada tanggal 5 Desember 2018 ( putra yang bernama Andreas usia 8 tahun)

${ }^{23}$ Wawancara dengan Bapak Jamhari, guru di SD Gayam Harjo. Pada tanggal 8 Desember 2018.( putra yang bernama Yunantor Yukarnain usia 9 tahun)
} 
Oleh sebab itu orangtua harus mempunyai solusi-solusi ketika dalam pembelajaran menghadapi hambatan sehingga mereka dapat mengatasinya. Bila mereka tidak dapat mengatasinya maka dikhawatirkan putra-putri mereka akan tersesat dalam pembelajarannya apalagi dalam hal ini adalah pembelajaran salat padahal itu harus diterapkan sejak dini kalau dalam penyampaiannya terdapat suatu hambatan yang tak bisa diatasi maka putra-putri mereka yang menjadi korban dan pendidikan tidak akan berjalan dengan baik. Putra-putri mereka akan melenceng ke hal yang negatif dan tidak mengenal tentang kwajibannya.

Tapi dalam hal ini responden yang peneliti wawancarai memang menemukan hambatan dalam penerapan metode pendidikan salat yang mereka terapkan pada putra-putri mereka, tapi mereka tanggap akan hal itu dan langsung mencarikan jalan keluar atau solusinya. Seperti yang dilakukan para responden mereka menangani kesulitan yang mereka hadapi dengan mencari masalahnya seperti dari putra-putri mereka yang nakal, bandel, ngeyel, malas, dll. Mereka menghadapinya dengan pendekatan-pendekatan yang dilakukan pada putra-putrinya dengan memberikan contoh langsung pada putra-putrinya dan menunjukkan kesalahan apa yang mereka lakukan dan menerangkan dari akibat yang akan didapat kelak ketika dia melakukan kesalahan itu. Hal ini mereka lakukan agar dalam menerapkan metode itu bisa berjalan dengan lancar dan bisa mencapai tujuan yang mereka harapkan seperti tujuan awal yaitu mengenalkan salat sejak usia dini.

Hal ini mereka lakukan karena mereka perduli akan pendidikan keagamaan putra-putri mereka terutama dalam hal pendidikan salat. Karena salat itu bila tidak diajarkan orangtua ketika masi kecil maka ketika anak itu sudah dewasa tidak bisa salat, maka orangtuanya yang akan mendapat dosa dari allah. Tidak itu juga mereka tahu bahwa kewajiban bagi orang Islam adala beribadah yaitu ibadah salat memang tidak salat saja tapi saalah satu yang terpenting adalah salat. Dari situlah mereka dengan metode yang mereka pakai dan segala usaha, mereka mengajarkan pendidikan salat pada putra-putrinya agar mereka di usia yang relatif muda sudah mengetahui kewajiban-kewajiban umat Islam dan dapat menjalankan kewajiban itu dengan sempurna. Sehingga diwaktu dewasa mereka akan terbiasa dan mereka tidak buta akan kewajiban mereka sebagai umat Islam.

Dari pernyataan responden diatas tentang solusi yang mereka gunakan ketika mengahadapi suatu permasalahan dalam penerapan metode pendidikan salat. Mereka langsung mengatasi dengan pendekatan-pendekatan yang mereka lakukan pada putra-putri mereka dengan memberikan arahan-arahan yang membuat anak mengerti dan dengan pengarahan yang membuat anak mau melakukan salat. Tapi kita juga harus tahu apakah metode itu baik untuk anak kita apa bukan. Dari situ kita juga perlu menengok metode kita apakah sesuai denga 
karakter putra-putri kita kalau tidak buat apa kita mempertahankan metode yang kita pakai lebih baik kita ganti dengan metode yang lebih bisa diterima oleh anak. Memang dengan pengarahan-pengarahan seperti ini yang perlu kita lakukan ketika menghadapi kesulitan dalam penerapan metode pendidikan salat untuk anak usia 5-10 tahun. Karena bila anak dibuat keras pada pendidikannya dengan dipukul, anak memang akan jera tapi anak akan terganggu dalam psikologisnya dan mentalnya dan bisa menumbuhkan sifat pendedam.

\section{Kesimpulan}

Berdasarkan penyajian dan analisis yang telah dilakukan di bab sebelumnya, maka dapat disimpulkan bahwa:

Metode yang dipakai oleh keluarga guru dalam mendidik salat putra-putri mereka adalah sebagai berikut: Dari 8 keluarga guru ditemui banyak sekali metode yang digunakan yaitu metode keteladanan, menegakkan disiplin, menghafal, mempraktekkan dan pembiasaan. Dari metode tersebut ada beberapa metode yang dominan dipakai oleh kerluarga guru yaitu yang dipake oleh keluarga Ibu Tentrem, Bapak Jarot Ansoro,Ibu Zulisti Sudarojah, Ibu Enggar, Bapak Paryoto dan Ibu Rini, untuk mendidik putra-putrinya yang berusia 5-10 tahun mereka memakai metode keteladanan dan pembiasaan. Karena dengan keteladanan anak bisa meniru gerakan dari orangtua mereka dan dengan pembiasaan mereka terbiasa untuk menjalankannya. Tapi ada juga yang menggunakan metode yang lain yaitu jamhari yaitu metode turunan dari orangtuanya. Tapi semua itu harus ada dukungan dari semua pihak agar bisa berjalan dengan baik terutama dari orangtua karena orangtua adalah orang yang paling berpengaruh dalam pertumbuhan anak.

Ada beberapa faktor yang menjadi hambatan dalam menerapkan metode pendidikan salat yaitu: acara televisi yang menyita banyak waktu, bermain dengan teman sebaya, lingkungan sekitar yang suka mempengarui hal-hal buruk sehingga membuat anak melupakan kewajiban mereka yaitu salat dan karena factor kesibukan orangtua.

Usaha yang mereka lakukan dalam mengatasi problematika metode pendidikan salat pada anak usia 5-10 tahun di keluarga guru di Padukuhan Kadipolo, Sendangtirto, Berbah, Sleman, Yogyakarta yaitu dengan memberikan motivasi serta penjelasan tentang salat dan manfaat salat. Dari penjelasan tersebut orangtua bisa mengatasi hambatan-hambatan yang mereka peroleh ketika menerapkan metode pendidik salat. Tapi ada juga mereka menggunakan hukuman yang mendidik semisal memberikan hukuman ketika anak melakukan kesalahan dan memberikan hadiyah ketika melakukan hal yang benar dalam pendidikan salat. 


\section{Daftar Pustaka}

Fuadudin, Pengasuhan Anak Dalam Keluarga Islam, kerjasama antara lembaga kajian agama dan gender, solidaritas perempuan dan the asian foundation, 1991.

Fuadudin, Pengasuhan Anak Dalam Keluarga Islam, Lembaga Kajian Agama dan Jender, 1999.

Daradjat Zakiah, Ilmu Jiwa Agama (Jakarta:Bulan Bintang,1970).

Zuharini dkk, Metode Khusus Pendidikan Agama (Surabaya : Usaha Nasional 1983)

Robinson, Philip, alih bahasa, hasan basari, Beberapa Persepektif Sosiologi Pendidikan (Jakarta Rajawali Prees, 1986), hal.58. 
Muhammad Sopiyana dan Septian Arief Budiman

\section{Lampiran}

Tabel 1. Literatur sebelumnya mengenai variabel relasional yang dipelajari dalam konteks Pendidikan Shalat

\begin{tabular}{|c|c|c|}
\hline Penulis & Subjek studi/negara & Usulan hubungan \\
\hline Syahrul Imam (2017) & $\begin{array}{l}\text { Upaya Guru Fiqih Dalam } \\
\text { Melaksanakan Ibadah } \\
\text { Salat Anak Kelas VIII Di } \\
\text { MTs Ngemplak Sleman } \\
\text { Yogyakarta/Indonesia }\end{array}$ & Pendidikan Shalat \\
\hline Susilowarni (2017) & 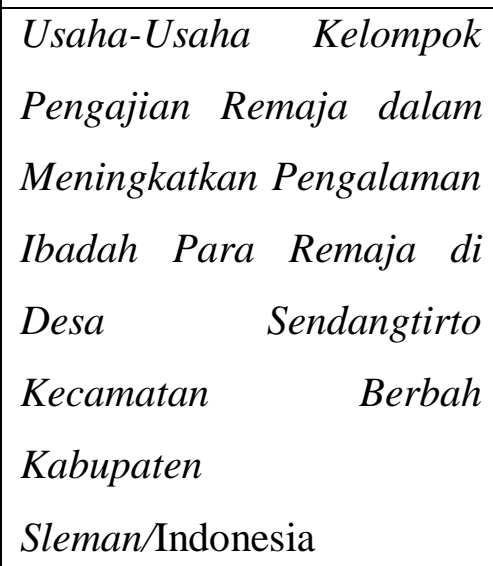 & Pendidikan Shalat \\
\hline $\begin{array}{l}\text { Barokah Wulandari } \\
(2015)\end{array}$ & 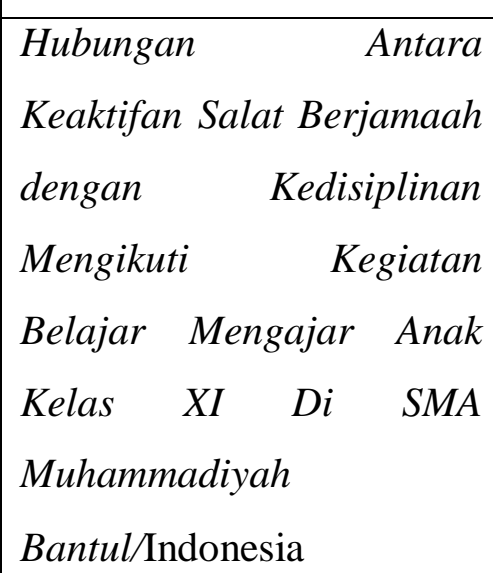 & Pendidikan Shalat \\
\hline
\end{tabular}

Sumber : Hasil Penelitian 
Metode Pendidikan Shalat pada Anak Usia 5-10 Tahun dalam Keluarga 